\title{
Fashion Involvement, Shopping Lifestyle dan Pembelian Impulsif Produk Fashion
}

\author{
Nadya Muslimatul Ummah ${ }^{1}$, Siti Azizah Rahayu ${ }^{1}$ \\ ${ }^{1}$ Fakultas Psikologi dan Kesehatan, UIN Sunan Ampel Surabaya
}

DOI: http://doi.org/10.29080/jpp.v11i1.350

\begin{abstract}
Impulsive buying often occurs in fashion especially when there are new trends and price discounts. This study aims to study a correlation between fashion involvement and shopping lifestyle with impulsive buying on fashion products. Having a quantitative correlational approach, this study involved 76 female students living in a boarding house. The results showed that fashion involvement and shopping lifestyle simultaneously had a significant relationship with impulsive buying of fashion products. Both variables contribute to the formation of impulsive buying behavior. Besides, each variable, both fashion involvement, and shopping lifestyle also has a significant relationship with impulsive buying
\end{abstract}

Keywords : Impulsive buying, Fashion involvement, Shopping lifestyle

\begin{abstract}
Abstrak : Pembelian secara impulsif seringkali terjadi pada produk pakaian terutama saat ada trend model baru dan tawaran potongan harga. Penelitian ini bertujuan untuk melihat hubungan fashion involvement dan shopping lifestyle dengan pembelian impulsif pada produk fashion. Menggunakan pendekatan kuantitatif korelasional, penelitian ini melibatkan 76 mahasiswi yang tinggal di kos sebagai subjek penelitian. Hasil penelitian menunjukkan bahwa fashion involvement dan shopping lifestyle secara simultan memiliki hubungan yang signifikan dengan pembelian impulsif pada produk fashion. Kedua variable tersebut ikut berkontribusi terhadap terbentuknya perilaku impulsif buying. Selain itu masing-masing variable baik fashion involvement maupun shopping lifestyle juga memiliki hubungan yang signifikan dengan pembelian impulsif.
\end{abstract}

Kata kunci : Pembelian impulsif, Fashion involvement, Shopping lifestyle

\section{Pendahuluan}

Pembelian secara impulsif seringkali dilakukan tanpa rencana namun dengan dorongan yang kuat dan perasaan senang (Verplanken dan Herabadi, 2001). Spontanitas, intensitas, motivasi, dan ketidakpedulian akan akibat dijelaskan oleh Engel, Blackwell dan Miniard (1995) sebagai dimensi dari pembelian secara impulsif tersebut. National Endowment for Financial Education (NEFE, 2010), menjelaskan bahwa orang Amerika

Corresponding Author: Nadya Muslimatul Ummah (e-mail: ummahnadya@gmail.com) Program Studi Psikologi Fakultas Psikologi dan Kesehatan UIN Sunan Ampel Surabaya, Jl. A. Yani 117 Surabaya, Jawa Timur, Indonesia 60237 
mengaku sebagai konsumen yang impulsif dengan tingkat lebih dari 87\%. Data dari CNN menunjukkan hasil riset yang mengungkapkan bahwa setengah dari generasi milenial Indonesia (50\%) dan Thailand (60\%) merupakan konsumen impulsif di Asia Pasifik yang itu dibuktikan dengan melakukan pembelian produk mewah secara tidak terencana. Hasil survei lainnya juga dilakukan oleh tajuk Women e-Commerce Survei yang menjelaskan bahwa perempuan di Indonesia memiliki kecenderungan impulsif atau spontan ketika sedang melakukan kegiatan belanja (Kompas.com 2019)

Engel dan Blacwell (1995) menjelaskan bahwa pembelian impulsif adalah pembelian yang tidak terencana sebelumnya. Mowen dan Minor (2001) menambahkan bahwa pembelian impulsif terjadi disebabkan karena suatu desakan hati yang secara tiba-tiba dan secara spontan tanpa memperhatikan akibat yang akan dialami. Loudon dan Bitta (1993) menjabarkan empat tipe pembelian impulsif yaitu pure impulse, suggestion impulse, reminder impulse, dan planned impulse. Pure impulse adalah proses pembelian yang dilakukan tanpa melakukan pertimbangan sedangkan suggestion impulse pembelian dengan mempersepsikan suatu saat akan memerlukannya. Adapun reminder impulse merupakan proses pembelian spontan ketika teringat stok barang sudah perlu dibeli, dan planned impulse adalah proses pembelian dilakukan ketika ada potongan harga atau diskon.

Kacen dan Lee (2002) juga menambahkan bahwa suasana hati, reaksi impulsif, identitas diri, faktor demografi, dan evaluasi normatif adalah sejumlah faktor yang mempengaruhi terjadinya pembelian impulsif. Faktor internal yaitu materialisme, harga diri, dan pemantauan diri dan faktor eksternal seperti jenis produk, pemasaran produk, pengaruh lingkungan sosial, tingkat ekonomi, dan faktor demografi mempengaruhi terbentuknya perilaku pembelian secara impulsif. Dari semua produk yang ada, produk fashion paling sering diminati dan dibeli secara spontan. Menurut Kaiser (2010) pakaian dapat memperlihatkan status sosial dan karakteristik individu. Kim dab Forney (2006) juga menjelaskan bahwa salah satu penyebab munculnya pembelian tidak terencana pada produk fashion adalah keterlibatan individu pada fashion (fashion involvement). Sejumlah faktor yang membentuk keterlibatan fashion adalah ekspresi diri, hedonisme, relevansi praktis, dan resiko pembelian (Sangadji \& Sopiah, 2013).

Fashion involvement adalah suatu tingkat ketertarikan individu pada jenis fashion seperti pakaian (Park dkk, 2006). Selain itu, Japarianto dan Sugiono (2011) juga menjelaskan bahwa keterlibatan fashion adalah ketertarikan individu terhadap produk pakaian yang disebabkan oleh kepentingan, kebutuhan, ketertarikan, dan nilai dari produk tersebut. Fashion involvement juga dapat diartikan sebagai penilaian terhadap produk fashion (Engel dkk, 1995). Sangadji dan Sopiah (2013) mengemukakan terdapat empat dimensi pada fashion involvement yaitu ekspresi diri, hedoisme, relevansi praktis, dan resiko pembelian. Ekspresi diri menunjukkan konsep diri individu, hedonisme adalah pemilihan produk yang dapat memberikan kesenangan, menarik, menggembirakan, dan terlihat mempesona. Relevansi praktis adalah pertimbangan manfaat, dan resiko pembelian mengandung makna bahwa suatu produk dapat memberikan ketidakpastian. Peter dan Olson (2013) juga menjelaskan dimensi yang menunjang pembentukan fashion involvement yaitu relevansi diri intrinsik dan relevansi diri situasional. Relevansi diri intrinsik adalah pengetahuan konsumen mengenai suatu produk melalui pengalamannya di masa lalu. Adapun relevansi diri situasional adalah membuat njadi ingin membeli produk tersebut dikarenakan terdapat diskon.

Hermanto (2016) dalam penelitiannya menemukan bahwa fashion invovement berpengaruh terhadap impulse buying behavior pada masyarakat Surabaya. Semakin seseorang tertarik pada dunia fashion, maka akan terus mengikuti perkembangan model terbaru dengan cara membeli secara tidak terencana pada setiap pakaian yang diinginkan. Setiadi dan Warmika (2015) juga melihat pengaruh fashion involvement terhadap impulse buying pada konsumen fashion di Kota Denpasar. 
Selain fashion involvement, ada juga faktor internal yang mendorong timbulnya pembelian secara impulsif yaitu shopping lifestyle (Kosyu, 2014). Shopping lifestyle menurut Betty Jackson (2004) dalah suatu ekspresi dalam lifestyle ketika berbelanja yang mencerminkan perbedaan status social. Cara kita melakukan kegiatan berbelanja akan mencerminkan status, martabat, dan kebiasaan. Menurut Levy (2009) shopping lifestyle adalah suatu gaya hidup yang mengacu pada bagaimana individu hidup, bagaimana cara menghabiskan uang, waktu, kegiatan pembelian, sikap dan pendapat mengenai dunia yang mereka tinggali. Japarianto dan Sugiharto (2011) menjelaskan bahwa shopping lifestyle adalah cara seseorang yang digunakan untuk memanfaatkan waktu dan uang pada suatu produk, pendidikan, hiburan, dan lain sebagainya.

Shopping lifestyle adalah gaya berbelanja yang dilakukan oleh individu untuk memenuhi gaya hidupnya yang terkadang harus mengorbankan sesuatu demi keinginanya. Faktor yang dapat mempengaruhi shopping lifestyle adalah penilaian terhadap merek, pengaruh yang disebabkan oleh iklan dan yang terpenting adalah kepribadian atau karakteristik yang dimiliki oleh individu tersebut. Prastia (2013) menegaskan bahwa gaya berbelanja itu menjadikan munculnya pembelian tidak terencana (Prastia, 2013). Faktor yang dapat mempengaruhi shopping lifestyle adalah penilaian terhadap merek, pengaruh iklan dan juga kepribadian yang dimiliki individu. Japarianto dan Sugiharto (2011) dalam penelitiannya menunjukkan bahwa shopping lifestyle berpengaruh signifikan terhadap pembelian secara impulsif.

Berdasarkan hasil wawancara pada mahasiswi Psikologi UIN Sunan Ampel Surabaya, diketahui bahwa mereka sering melakukan pembelian tidak terencana ketika tertarik pada model fashion tertentu. Hal ini banyak dilakukan oleh para mahasiswi yang bertempat tinggal di kos dan jauh dari kontrol orang tua (wawancara pada tanggal 10 Desember 2019). Mereka juga bahkan setiap hari memakai pakaian yang fashionable, yang mengikuti tren model fashion terbaru. Dengan memakai pakaian yang fashionable, maka dapat diasumsikan bahwa mereka memiliki keterlibatan dengan fashion. Kondisi anak kos yang memiliki ketertarikan fashion, sedang jauh dari orang tua, serta tidak terkontrol keuangannya dapat menjadi faktor timbulnya pembelian tidak terencana atau pembelian impulsif (observasi pada tanggal 13 Desember 2019).

Pakaian sangat erat kaitannya dengan karakteristik pribadi individu sehingga menyebabkan kecenderungan dalam pembelian. Keinginan untuk selalu berpenampilan menarik menjadikan seseorang melakukan pembelian yang tidak direncanakan. Dalam suatu penelitian Seo, Hathcote dan Sweaney (2001) terlihat hubungan yang positif antara tingkat fashion involvement dengan pembelian impulsif. Konsumen dengan ketertarikan fashion yang tinggi akan lebih memungkinkan untuk membeli pakaian tanpa rencana. Semakin individu tertarik pada dunia fashion, maka mereka akan terus mengikuti perkembangan model terbaru dan membeli secara tidak terencana pakaian yang diinginkan. Gregory Stone dalam Savitrie Dian (2008) mengatakan bahwa pakaian adalah alat untuk mengekspresikan diri dan menunjukkan gaya hidup. Shopping lifestyle adalah gaya hidup ketika berbelanja yang disesuaikan dengan status sosialnya dalam masyarakat. Kaiser (2010) juga menegaskan bahwa pakaian dapat memperlihatkan status sosial dan karakteristik individu.

Sejumlah penelitian menunjukkan bahwa fashion involvement dan shopping lifestyle berhubungan dengan pembelian secara impulsif. Tryanti (2018) dalam penelitiannya melihat pengaruh yang signifikan antara fashion involvement dengan impulse buying. Penelitian Suchida (2019) juga menunjukkan ada pengaruh yang signifikan dari fashion involvement, shopping lifestyle, hedonic shopping value, dan positive emotion terhadap perilaku membeli secara impulsif. Selain itu, Dian (2016) dalam penelitiannya menggambarkan ada pengaruh yang signifikan antara fashion involvement dengan impulse buying. Individu yang melihat berbagai brand fashion dengan kualitas tinggi memiliki keinginan untuk mendapatkan model terbaru sehingga mereka melakukan 
pembelian tidak terencana. Zefanya, dkk (2018) juga mengatakan bahwa shopping lifestyle, fashion involvement, dan sales promotion berperan pada terbentuknya pembelian secara impulsif.

Dari latar belakang yang telah dipaparkan di atas, fenomena perilaku membeli secara impulsif masih banyak terjadi dan penting untuk dilihat lebih lanjut. Banyaknya mahasiswi UIN Sunan Ampel dengan kondisi mayoritas tinggal jauh dari orang tua terlihat memiliki tingkat keterlibatan yang tinggi dengan produk fashion. Variabel keterlibatan terhadap fashion tampaknya dialami oleh banyak mahasisi UIN Sunan Ampel dengan penampilan mereka yang selalu mengikuti trend mode terbaru. Namun gaya belanja (shopping lifestyle) yang masih bervariasi menunjukkan usaha untuk menentukan dimana status sosial mereka. Penelitian ini akan melihat pengaruh keterlibatan fashion dan shopping lifestyle mahasiswi terhadap perilaku membeli secara impulsif.

\section{Metode Penelitian}

\section{Jenis penelitian}

Berdasarkan tujuan masalah yang ingin dicapai, maka penelitian ini menggunakan pendekatan kuantitatif dengan metode korelasional. Pendekatan kuantitatif adalah suatu penelitian yang didalamnya terdapat angka-angka, data numerik, dan hasil penelitian yang di olah menggunakan data statistik dengan tujuan menguji hipotesis sehingga diketahui signifikansi antar variabel yang di teliti. Sedangkan metode korelasional adalah penelitian yang ditujukan untuk mengetahui hubungan antar variabel yang diteliti. Peneliti ingin melihat hubungan fashion involvement dan shopping lifestyle dengan pembelian impulsif produk fashion.

\section{Populasi dan Sampel}

Populasi dalam penelitian ini adalah seluruh mahasiswi aktif Fakultas Psikologi dan Kesehatan UIN Sunan Ampel Surabaya yang berjumlah 409 orang. Teknik pemilihan sampel dilakukan menggunakan purposive technique sampling dimana karakteristik subjek telah ditentukan. Sampel dalam penelitian ini berjumlah 76 mahasiswi dengan karaketritik berstatus sebagai mahasiswi Fakultas Psikologi dan Kesehatan UIN Sunan Ampel Surabaya, berada pada semester 2-8, berumur 18-21 tahun, dan bertempat tinggal di kos dengan uang saku lebih besar atau sama dengan 1 juta per bulan.

\section{Teknik Pengambilan Data}

Teknik pengambilan data dalam penelitian ini menggunakan menggunakan penyebaran kuesioner kepada subjek yang sesuai dengan karakteristik yang telah ditentukan. Instrumen pengukuran variabel pembelian secara impulsif, fashion involvement, dan shopping lifstyle menggunakan alat ukur yang dikembangkan oleh Kusmaningsih (2017).

\section{Analisis Data}

Analisis data dalam penelitian ini menggunakan analisis regresi linier berganda dengan bantuan software SPSS versi 24.0.

\section{Hasil Penelitian}

Hasil Uji F digunakan untuk mengetahui apakah terdapat pengaruh yang simultan (bersama-sama) antara variabel bebas dengan variabel terikat. Pada tabel 1 diketahui nilai signifikansi sebesar 0,000 $<0,05$ dan nilai $F_{\text {hitung }}$ sebesar 48,120 $>3,12$. sehingga dapat diartikan bahwa fashion involvement dan shopping lifestyle berpengaruh secara simultan (bersama-sama) terhadap pembelian impulsif. 
Tabel 1

\begin{tabular}{cccccc}
\multicolumn{7}{c}{ Uji F } & F & Sig. \\
\hline Model & Sum of Square & Df & Mean Square & 48.120 & .000 \\
\hline Regression & 4030.627 & 2 & 2015.313 & 41.881 & \\
\hline Residual & 3057.320 & 73 & & \\
\hline Total & 7087.947 & 75 & & \\
\hline
\end{tabular}

Saat diuji secara parsial, nilai signifikansi variabel fashion involvement sebesar 0,010< 0,05 dan nilai thitung sebesar 2,636 > 1,66571. Nilai signifikansi yang lebih kecil dari 0,05 menunjukkan ada hubungan yang signifikan antara fashion involvement dengan perilaku pembelian impulsif produk fashion. Demikian pula dengan nilai signifikansi variabel shopping lifestyle sebesar 0,000 $<0,05$ dan nilai thitung sebesar 4,865 > 1,66571. Nilai tersebut juga berarti bahwa shopping lifestyle secara signifikan berhubungan dengan pembelian impulsif.

Tabel 2

Koefisien

\begin{tabular}{cccccc}
\hline Model & \multicolumn{2}{c}{$\begin{array}{c}\text { Unstandardized } \\
\text { Coefficients }\end{array}$} & $\begin{array}{c}\text { Standardized } \\
\text { Coefficients }\end{array}$ & T & Sig. \\
& B & Std. Error & Beta & & \\
\hline $\begin{array}{c}\text { (Constant) } \\
\text { Fashion } \\
\text { Involvement } \\
\text { Shopping } \\
\text { Lifestyle }\end{array}$ & -10.176 & 5.457 & & -1.865 & .066 \\
\hline a. Dependent Variable: pembelian impulsif $(\mathrm{Y})$ & .331 & .126 & .285 & 2.636 & .010 \\
\hline
\end{tabular}

Selanjutnya adalah nilai koefisien determinasi $\mathrm{R}$ Square sebesar 0,569 yang menunjukkan bahwa variabel bebas (fashion involvement dan shopping lifestyle) mampu menjelaskan variabel terikat (pembelian impulsif) sebesar 56,9\%.

Tabel 3

Koefisien Determinasi $\left(\mathrm{R}^{2}\right)$

\begin{tabular}{ccccc}
\hline Model & $\mathbf{R}$ & R Square & $\begin{array}{c}\text { Adjusted R } \\
\text { Square }\end{array}$ & $\begin{array}{c}\text { Std. Error of } \\
\text { the Estimate }\end{array}$ \\
1 & .754 & .569 & .557 & 6.472 \\
\hline
\end{tabular}

\section{Pembahasan}

Hasil analisis data menunjukkan terdapat hubungan yang signifikan antara variabel fashion involvement dengan pembelian impulsif. Nilai hubungan positif menjelaskan semakin tinggi nilai fashion involvement maka akan semakin meningkat nilai pembelian impulsif. Dengan kata lain semakin tinggi keterlibatan individu dalam mengikuti trend fashion maka semakin tinggi juga kemungkinan mereka akan melakukan pembelian secara impulsif. Tryanti (2018) dalam penelitiannya juga melihat ada hubungan yang signifikan antara fashion involvement dengan impulse buying. Hermanto (2016) juga menegaskan bahwa semakin individu tertarik pada dunia fashion, maka mereka akan terus mengikuti perkembangan model terbaru sampai memaksakan diri untuk membeli secara tidak terencana pakaian yang diinginkan. Tingginya ketertarikan para mahasiswi terhadap berbagai tren model pakaian terbaru dipengaruhi oleh iklan dan pengaruh lingkungan sekitar mereka. Setiadi dan Warmika (2015) juga mengatakan 
bahwa fashion involvement berpengaruh terhadap perilaku impulse buying pada konsumen fashion.

Ketertarikan terhadap fashion seperti pakaian pada mahasiswi Psikologi UIN Sunan Ampel Surabaya menggiring mereka cenderung berperilaku impulsif dalam membeli pakaian. Hal itu dijelaskan oleh Kim dan Forney (2006) bahwa salah satu penyebab munculnya pembelian tidak terencana pada produk fashion adalah keterlibatan individu pada fashion. Rata-rata mahasiswa yang bertempat tinggal di kos lebih sering melakukan impulsive buying karena merasa tidak ada kontrol dari orang tua. Penelitian Dian (2016) menggambarkan fashion involvement membuat individu lebih sering melihat berbagai brand fashion dengan kualitas tinggi dan itu mendorong mereka mendapatkan model terbaru dan akhirnya melakukan pembelian yang tidak terencana.

Menurut Kaiser (2010) pakaian dapat memperlihatkan status sosial dan karakteristik individu. Kondisi para mahasiswi kos dengan uang saku perbulan lebih dari 1 juta ke atas membuka peluang untuk menggunakan uang yang dimiliki dengan bebas dan tidak adanya kontrol dari orang tua. Hal itu membuat mereka merasa dapat menentukan sendiri dan memenuhi keinginannya untuk berpenampilan menarik. Kondisi itu dijelaskan oleh Sangadji dan Sopiah (2013) bahwa ekspresi diri, hedonisme, relevansi praktis, dan resiko pembelian adalah sejumlah faktor yang membentuk keterlibatan fashion. Japarianto dan Sugiono (2011) juga menegaskan bahwa tingkat ketertarikan yang sangat tinggi terhadap fashion menjadikan individu memiliki keinginan untuk mempunyai penampilan yang menarik dengan melakukan pembelian secara tiba-tiba terhadap pakaian.

Hasil analisis lainnya menunjukkan adanya hubungan yang signifikan antara variabel shopping lifestyle dengan pembelian impulsif. Semakin tinggi nilai shopping lifestyle maka akan semakin meningkat perilaku pembelian impulsif. Penelitian Japarianto dan Sugiharto (2011) juga menunjukkan bahwa shopping lifestyle berpengaruh signifikan terhadap pembelian secara impulsif. Gaya hidup mahasiswi Psikologi UIN Sunan Ampel Surabaya ketika berbelanja memiliki kecenderungan berperilaku impulsif ketika melakukan pembelian. Hal ini diperkuat dengan mahasiswi yang bertempat tinggal di kos dengan uang saku perbulan lebih dari 1 juta keatas. Mereka memiliki banyak waktu dan cukup uang untuk membeli apa yang diinginkan. Selain itu Kesempatan jauh dari orang tua dan tidak adanya kontrol dari orang tua digunakan untuk memenuhi gaya hidup yang dimiliki. Hal itu yang digambarkan oleh Prastia (2013) yang menjadikan pembelian tidak terencana. Selain pengaruh iklan yang mereka terima tentu saja kepribadian yang dimiliki individu membentuk pola shopping lifestyle. Jika gaya hidup seseorang ketika berbelanja meningkat pada produk pakaian, maka kecenderungan untuk membeli secara tiba-tiba juga akan semakin meningkat ketika melihat model pakaian terbaru.

Mahasiswi yang bertempat tinggal di kos memiliki waktu luang dan uang saku yang banyak. Mereka sering menggunakannya untuk berbelanja produk pakaian terbaru. Japarianto dan Sugiono (2011) juga mengatakan bahwa berbelanja adalah sebuah gaya hidup yang digemari banyak kalangan. Untuk memenuhi gaya hidup, individu bahkan rela mengorbankan sesuatu yang dimiliki untuk keinginannya. Hal ini dapat memicu perilaku pembelian tidak terencana karena banyak waktu dan uang yang terbuang untuk mencapai keinginan. Hal itu juga ditegaskan oleh Kosyu (2014) bahwa selain fashion involvement, ada juga faktor internal yang mendorong timbulnya pembelian secara impulsif yaitu shopping lifestyle. Shopping lifestyle adalah gaya berbelanja yang dilakukan oleh individu untuk memenuhi gaya hidupnya yang terkadang harus mengorbankan sesuatu demi keinginanya yang terkadang munculnya pembelian tidak terencana (Prastia, 2013). Faktor yang dapat mempengaruhi shopping lifestyle adalah penilaian terhadap merek, pengaruh iklan dan juga kepribadian yang dimiliki individu.

Pengaruh secara simultan variabel fashion involvement dan shopping lifestyle terhadap pembelian impulsif juga menjadi hasil dari penelitian ini. Nilai R Square sebesar 
0,569 mampu menjelaskan bahwa 56,9\% fashion involvement dan shopping lifestyle berkontribusi terhadap terbentuknya perilaku pembelian impulsif sedangkan sisanya sebesar 43,1\% dijelaskan oleh variabel lain. Dengan kata lain perilaku membeli pakaian secara impulsif terbentuk dari fashion involvement, shopping lifestyle dan faktor lainnya. Hal itu didukung oleh penelitian Suchida (2019) yang menunjukkan ada pengaruh yang signifikan dari fashion involvement, shopping lifestyle, hedonic shopping value, dan positive emotion terhadap perilaku membeli secara impulsif. Demikian pula pada penelitian Zefanya, dkk (2018) yang mengatakan bahwa shopping lifestyle, fashion involvement, dan sales promotion berperan pada terbentuknya pembelian secara impulsif.

\section{Daftar Pustaka}

Betty R, Jackson. Michael Ivlc. Kee. (2004). Audit Information Dissemination, Tax Payer Communication and Tax Compliance: An Experimental Investigation of Inderect Audit Effect. The National Tar Association Minneapolis MN

Engel, J Blackwell, R \& Miniard, P. (1995). Perilaku Konsumen. Jakarta: BinarupaAksara Hermanto, A. (2016). The Influence of Financial Condition, Size Company, and Reputation Auditor the Previos Year on Audit Opinion Going Concern. Jurnal Ilmu dan Riset Akuntansi. Vol. 5, No. 9

Japarianto, E \& Sugiono, S. (2011). Pengaruh Shopping Lifestyle dan Fashion Involvement terhadap Impulsif Buying Behavior Masyarakat Hight Income Surabaya. Journal Manajemen Pemasaran. 6 (1). Pp 31-41

Kacen, J.J, Lee, J.A. (2002). The Influence of Culture on Consumer Impulsif Buying Behavior. Journal of Consumer Psychology. Vol.12 (2), pp 163-176

Kaiser, Ahmed, Manzoor A. Thokar, Abu baker S. Toboli, Bashir A. Fomda, Gulnaz Bashir. (2010). Extended Spectrum Beta-Lectamase Mediated Resistance in Eschrichia Coli in a Tertiary Care Hospital in Kashmir, India. African Journal of Microbiology Research: 4(24), 2721-2718

Kaiser, Ahmed, Manzoor A. Thokar, Abu baker S. Toboli, Bashir A. Fomda, Gulnaz Bashir. (2010). Extended Spectrum Beta-Lectamase Mediated Resistance in Eschrichia Coli in a Tertiary Care Hospital in Kashmir, India. African Journal of Microbiology Research: 4(24), 2721-2718

Kim, P. J \& Forney. (2006). A Structural Modal of Fashion-Oriented Impulse Buying Behavior. Journal of Fashion Marketing and Management. Vol. 10, pp. 433-446

Kosyu, D.A. (2014). Pengaruh Hedonic Shopping Motives terhadap Shopping Lifestyle dan Impulse Buying (Survei pada Pelanggan Outlet Stradivarius di Galaxy Mall Surabaya). 14(2). 1-7

Levy, Michael daan Barton A, Weitz. (2009). Retailing Management. Seventh Edition. International Edition, McGraw Hill

Loudon, D.L dan Della Bitta, A.J. (1993). Consumer Behavior: Consepts and Application.Singapore:McGrowHill,In

Mowen, John C dan Michael Minor. (2001). Perilaku Konsumen (Jilid 1) Edisi Kelima. Jakarta: Erlangga

NEFE. (2010). https://www.nefe.org . (Diakses pada tanggal 23 April 2020)

Park, dkk. (2006). A Structural Model of Fashion-Oriented Impulse Buying Behavior. Journal of Fashion Marketing and Management. Vol,10. Pp,433-446

Peter dan Olson. (2013). Perilaku Konsumen dan Strategi Pemasaran. Edisi Kesembilan, Diterjemahkan oleh: Diah Tantri Dwiandani. Jakarta: Salemba Empat

Prastia, F.E. (2013). Pengaruh Shopping Lifestyle, Fashion Involvement dan Hedonic Shopping Value terhadap Impulse Buying Behavior Pelanggan Toko Elizabeth Surabaya. Jurnal Manajemen dan Kewirausahaan. Vol, 17. No,2

Sangadji, E.M \& Sopiah. (2013). Perilaku Konsumen. Yogyakarta: ANDI 
Savitrie, Dian. (2008). Pola Perilaku Pembelian Impulsif

Seo, J.Hathcote. M.J \& Sweaney, L.A. (2001). Casualwear Shopping Behavior of College Menin Georgia. Journal of Fashion Marketing and Management. 5. 208-222

Setiadi, I. M \& Warmika, I. G. (2015). Pengaruh Fashion Involvement terhadap Impulse Buying Konsumen Fashion yang Dimediasi Positive Emotion Di Kota Denpasar. EJurnal Manajemen Unud. Vol. 4, 1684-1700

Verplanken, B \& Herabadi,A. (2001). Individual Differences in Impulse Buying Tendency: Feeling and No Thingking. European Journal of Personality. Vol 15 